\title{
Lithic resources as a proxy for the social use of territory among hunter-gatherers of Central Chile
}

\author{
Luis Cornejo B. ${ }^{1}$, Patricio Galarce C. ${ }^{2}$, Miguel Saavedra V. ${ }^{3}$, \\ Lorena Sanhueza R. ${ }^{4}$ \\ 1. Anthropology Department, Universidad Alberto Hurtado. Almirante Barroso 10, Santiago, Chile. \\ Email: lcornejo@uahurtado.cl \\ 2. Archeos Chile Consultores en Arqueología. Parcela 266, El Molino, Culipram, Melipilla, Chile. \\ Email: patogalarce@yahoo.es \\ 3. Anthropology Department, Universidad de Chile. Ignacio Carrera Pinto 1045, Ñuñoa, Santiago, Chile. \\ Email: loresan@uchile.cl \\ 4. Independent Researcher. Santiago, Chile. Email: masvi2@gmail.com
}

\begin{abstract}
:
This paper presents the results of a study of the composition of lithic raw materials from the contexts of archaeological sites of hunter-gatherers of Central Chile (latitudes $33^{\circ}$ to $34.5^{\circ} \mathrm{S}$ ) between 5000 to 1000 years BP. This territory is characterized by a wide distribution of certain coarse and medium-grained lithic raw materials (andesite, basalt and granite), preferably used in low formatted tools, and the specific location of those of fine grain (obsidian and siliceous rocks), suitable for bifacial reduction, only in some localities. In this analysis, 22 sites have been included, each of which presents different proportions of these raw materials in their context, a set that, when analysed in terms of the diversity of each case, generated clear spatial groupings which were ratified by means of a principle component analysis. These groupings of sites are located in direct association with the lithic landscape of different localities within the region, although we propose that the simple cost-benefit explanation would not account for their formation. According to the authors, these groups would be marked by behaviours that can only result from social restrictions on access to certain sources of these raw materials, especially considering that the distances between their location and the position of the different sources in several cases is not too large to be considered a factor in itself. These restrictions could be interpreted as the existence of socially different groups within the study area, a question that is compared with ethnographic data currently available on the size of the territories of different groups of hunter-gatherers and their annual mobility ranges.
\end{abstract}

Keywords: lithic raw materials; hunter-gatherers; territory; spatial analysis; Central Chile

\section{Introduction}

The concept of territory as it applies to hunter-gatherer groups has been a constant in anthropological and archaeological discussions. While this concept has probably been used since these fields first appeared, it was not until the 1970s that a systematic set of ideas emerged.

Published by the School of History, Classics and Archaeology, University of Edinburgh ISSN: 2055-0472. URL: http://journals.ed.ac.uk/lithicstudies/ 
Situated within the cultural ecology current that characterized anthropology and archaeology at the time, Dyson-Hudson and Smith (1978) conducted one of the first modern syntheses of the concept, proposing that a territory corresponds to the area that is considered to belong to a certain group and has a perimeter that is defended, through violent repulsion or by the implementation of ways of communicating that ownership. According to the model developed by those authors, this defensive behaviour would favour a group or certain individuals in terms of costs and benefits. This idea was certainly taken up by processual and neo-evolutionary archaeology as one element in understanding how hunter-gatherers used a space (e.g., Binford 1979: 260; Kelly 2013: 77-113).

At the core of this proposal is the notion that the territory corresponds to an area, meaning a delimited portion of a continuous physical space, that can even be described by a mathematical function (e.g., Freeman \& Anderies 2015). However, even before Dyson-Hudson and Smith (1978) put forward their proposal, other scholars had pointed out that, for hunter-gatherers, it was not the space by itself that had to be defended. In a comparative study of primates, carnivores, and human hunter-gatherers, from an evolutionary lens, King (1976) concluded that hunter-gatherer groups placed more emphasis on control over resources than on the exclusive occupation of a given portion of space. Along the same line, Ingold (1986) proposed a distinction between territorial behaviour and tenure, the claiming of an exclusive right of use of certain places and spaces, in which hunter-gatherer groups took a one-dimensional approach, meaning they concentrated on controlling places where certain resources existed, rather than a two-dimensional conception, i.e., involving an entire area. This opens up the possibility that a single continuous portion of space could have been used by different groups, each of which claimed certain resource sources.

This last perspective has been used previously (Cornejo \& Sanhueza 2011) to discuss the existence of hunter-gatherer groups in the Andes of Central Chile that comprised differentiated social units. In addition to other characteristics proper to their habitus (Bourdieu 1977), these groups were differentiated according to their appropriation of lithic resources, establishing specific differences in the access that each of them had to certain raw materials, namely obsidian and siliceous rocks. In this article, we intend to expand this perspective to the entire territory of Central Chile (Figure 1), using access to lithic raw material as an indicator of the social differences that would have existed among hunter-gatherer populations that lived in this area between 5000 and 1000 BP.

\section{Study area}

Central Chile, situated between $33^{\circ}$ and $34.5^{\circ} \mathrm{S}$ latitude, is a narrow territory that stretches hardly more than $120 \mathrm{~km}$ east to west, from the Andes Mountains to the Pacific coast. Palaeoclimatic studies conducted here (Villa-Martinez et al. 2003; 2004) indicate that beginning around $5000 \mathrm{BP}$, encompassing the period of our study, Holocene conditions were established that are similar to those found today. These conditions are characterized by a temperate climate determined by the latitude, a marked maritime influence, and an intense altitude gradient, which has led to the formation of five distinct geographical features: the Andes Mountains, the Central Valley, the Coastal Range, and the coastline itself. In the northern part of the Central Valley lies yet another special territory called the Cordón de Chacabuco, a low-lying chain of mountains that runs between the Andes and the Coastal Range. While not very extensive, it is of great interest here.

Within this region, hunter-gatherer studies have focused on the mountains of the Andes (Cornejo et al. 2000; 2005; Cornejo \& Sanhueza 2003; 2011; Cornejo \& Simonetti 1993; 1997; Galarce \& Peralta 2003; Planella et al. 2005) and on the Cordón de Chacabuco (Cornejo \& Saavedra 2017; Hermosilla 1994; Hermosilla et al. 1995; Reyes \& Contreras 2017; Stehberg \& 
Pinto 1980;). The other three main geographic features of the region present disparate information about the presence of hunter-gatherers. The Central Valley has been extensively surveyed (Cornejo et al. 2003; 2012; Sanhueza et al. 2007), and does not present records of hunter-gatherers, while the coast and its mountain range do present some evidence of these populations, although studies have been very limited and little to no advances have been made in the past 25 years (Falabella \& Planella 1991; Gajardo Tobar 1958; Hermosilla \& Ramírez 1985; Jerardino et al. 1992; Ramírez et al. 1991).

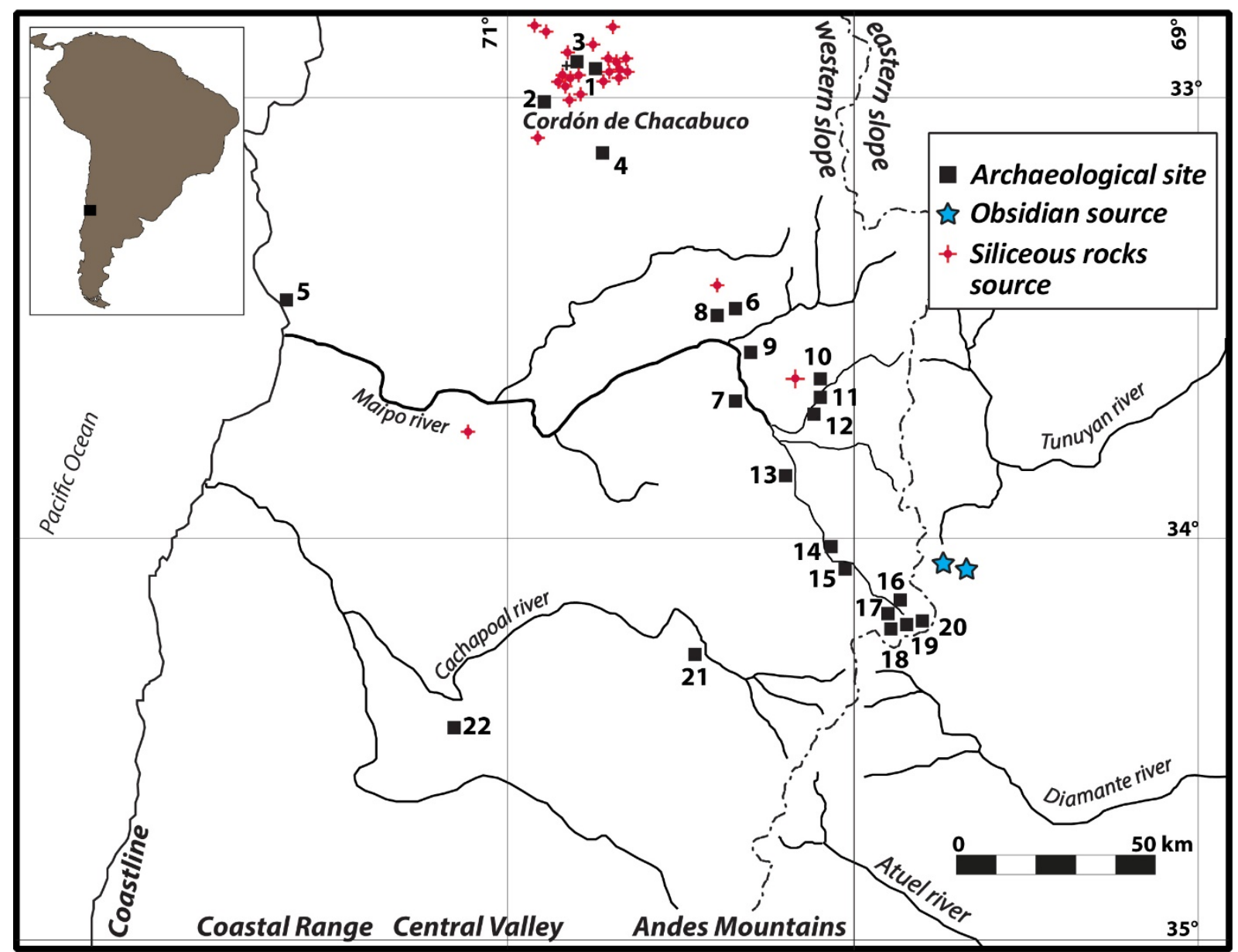

Figure 1. Study area showing the location of archaeological sites

The available information tells us that the hunter-gatherer way of life in Central Chile stretches back close to 13,000 years and lasted until the end of the 19th century (Cornejo 2010; Cornejo et al. 1998). Most of this sequence is known from a small number of relatively isolated sites. However, for 5000 BP onward, a body of information has been developed that has enabled researchers to propose a series of hypotheses about the historic, social, and technological development of this way of life (Cornejo \& Galarce 2010; Cornejo \& Saavedra 2017; Cornejo \& Sanhueza 2003; 2011; Cornejo \& Simonetti 1997). One of the most interesting aspects in this scenario is the coexistence of hunter-gatherer groups with more sedentary horticulturalist groups with well-developed ceramic traditions and a growing degree of economic dependence on agricultural crops. Furthermore, for the Andes Mountains, and the Maipo River basin specifically, researchers have proposed that two socially distinct groups existed that differed in the shape of their camps, in their relations with horticulturists, and in their use of raw materials (Cornejo \& Sanhueza 2011). This proposal has been very helpful for understanding how these populations defined their territory, based on access to different lithic raw materials found in the area. 


\section{Availability of lithic raw materials}

In the lithic landscape of Central Chile, certain raw materials are widely distributed, while others are found only in very specific places. Given that, the geology has been intensely influenced by the formation of the Andes Mountains, the most commonly found rocks are andesites, basalts, and granite. These include a variety of medium and coarse-grained raw materials that present in different ways, as layers or rounded stones of tectonic, alluvial, or volcanic origin. These rocks are hardly suitable for complex stone reduction processes such as bifacial knapping, but they are very suitable for producing relatively simple tools for scraping, flatting out, and crushing. Additionally, a series of located geological events has produced finegrained rocks, especially siliceous rocks and obsidian, with predictable fracturing planes that are especially suited to bifacial reduction, but also produce very useful live edges. These sources are only found in some specific places.

Within this scenario, the alluvial basin of the Central Valley offers a lithic landscape composed primarily of medium and coarse-grained rocks, while fine-grained rocks, most suitable for bifacial reduction, are notably absent. However, as mentioned above, for the sector of the Central Valley studied herein there are no records of hunter-gatherers; the first populations to appear there were semi-sedentary horticulturists, around $1800 \mathrm{BP}$. These groups would have had to devise ways of accessing sources of quartz, siliceous rocks and obsidian, which they used to make more elaborate bifacial tools, especially projectile points.

Within this "lithic mega-landscape," the rocks of greatest interest are those that were highly valued by hunter-gatherer groups for their stone industries, and these are found only in very localized spots. Using the frequency with which these rocks appear in archaeological contexts, we were able to map possible territories, differentiated by access to these resources.

Obviously, obsidian offers the best kind of information for this approach, as there is a wellproven methodology to determine the precise source of specimens of that stone found at each site. In previous studies (Cortegoso et al. 2014; 2020; Durán et al. 2004; Sanhueza et al. in press) it was identified, rather precisely, that the sources of obsidian are located in the southern part of our region of interest, exclusively in the high Andes, with two very close yet quite distinct sources identified: Arrollo Paramillos and Laguna del Diamante (Figure 1), about 150 $\mathrm{km}$ south of our area of study in Arroyo Las Cargas. Thus, obsidian was the most localized of the raw materials that comprise the lithic landscape of Central Chile.

Sources of siliceous rocks, for their part, are present in all geographic features except for the above-mentioned Central Valley, although each source presents different features. Thanks to its geological history, the Cordón de Chacabuco has abundant siliceous rocks available, with more than 30 sources identified to date (Figure 1), most of them microcrystalline hydrothermal varieties and silicified volcanic rocks (Aguilera 2012; Castelleti \& García 2007). This means that the Cordón de Chacabuco is, in principle, the locality with the most widely available siliceous rock sources, several of which also contain evidence of extraction and processing. For its part, the Andean Maipo Valley has been extensively surveyed, yet to date only two sources of siliceous rocks have been recorded (Cornejo \& Sanhueza 2011; Ibacache \& Cantarrutti 2007), both hydrothermal, located on the northern slopes of the Maipo River basin, and classified as provisioning and processing sites (Figure 1). Lastly, on the coast and in its mountain range, as mentioned, archaeological studies have been few, with no reports of specific siliceous rock sources that were exploited in the past. However, both of these areas present abundant geological information about the presence of quartz in veins or seams of different kinds of rocks (Godoy 1994; Parada 1992). These are widely distributed in the area and, as we shall see below, were indeed used by hunter-gatherers. Furthermore, at least one sector of the Coastal Range has been identified (Nasi \& Thiele 1982) in which siliceous rocks are likely present, owing to the geology (Figure 1). 


\section{Lithic raw materials and territory}

Although, archaeological studies of hunter-gatherer contexts have been uneven in the different geographical features of Central Chile, it is still possible to construct a scenario that addresses the problem we have outlined here for the Andes Mountains, the Cordón de Chacabuco, and the Pacific coast. To do so, our study focused on the by-products of reduction processes and not on manufactured tools, especially bifacial ones, which can be carried over long distances, and as such are a better indicator of exchange and interaction than of territoriality. The by-products of reduction, in comparison, offer much more direct information about the activities carried out at each site, and would have depended upon the raw material that each group possessed. Additionally, by-products of reduction are much more frequently found in archaeological contexts and thus enable us to include settlements with a low density of remains.

For this task, we have used a simplified classification system for the raw materials recorded, focusing on obsidian, siliceous rocks, and quartz. In order to determine the relative importance of each of these high-quality rocks, we have also included the category of medium and coarse-grained rocks (MCG rocks), which encompasses a wide variety of andesites, basalts, and granites. This classification, and the proportions of by-products found for each category at each site, can be observed in Table 1. Other raw materials that do not fall under this classification appear in different contexts, but because they are ultra-localized or found in very low proportions, we have not included them in this analysis.

Table 1. Types, proportions, and diversity measures for raw materials found at the sites studied

\begin{tabular}{lcccccc}
\hline Site & Quartz & Obsidian & Siliceous rocks & MCG rocks & $\boldsymbol{H}$ & $\boldsymbol{H} \boldsymbol{\alpha}$ \\
\hline 1) Loma La Vainilla 1 & 0.1 & 0.0 & 98.9 & 1.0 & 0.07 & 4.8 \\
2) Llanos de Rungue 6 & 0.9 & 0.3 & 96.5 & 2.3 & 0.18 & 13.2 \\
3) Los Valles 4 & 0.2 & 0.2 & 96.3 & 3.2 & 0.17 & 12.6 \\
4) Carmen Alto 6 & 10.8 & 0.5 & 71.6 & 17.1 & 0.81 & 58.3 \\
5) LEP-C & 26.0 & 0.4 & 1.0 & 72.6 & 0.65 & 46.8 \\
6) La Batea 1 & 0.0 & 6.7 & 90.7 & 2.6 & 0.37 & 26.3 \\
7) Condominio 1 & 0.0 & 0.0 & 44.4 & 55.6 & 0.69 & 49.6 \\
8) El Manzano 1 & 0.1 & 7.5 & 90.1 & 2.3 & 0.38 & 27.5 \\
9) Las Morrenas 1 & 1.0 & 3.8 & 69.3 & 25.9 & 0.77 & 55.8 \\
10) Las Covachas & 3.4 & 79.3 & 17.2 & 0.0 & 0.60 & 43.5 \\
11) El Aro & 0.7 & 72.3 & 27.0 & 0.0 & 0.62 & 45.0 \\
12) El Plomo & 0.4 & 64.7 & 18.5 & 16.4 & 0.91 & 65.9 \\
13) Cipreses & 4.0 & 28.2 & 63.6 & 4.2 & 0.91 & 65.4 \\
14) El Olvido & 5.3 & 38.3 & 48.9 & 7.4 & 1.07 & 77.0 \\
15) Las Perdidas & 2.6 & 59.2 & 23.2 & 15.0 & 1.03 & 74.3 \\
16) Los Queltehues & 0.1 & 65.6 & 31.7 & 2.6 & 0.74 & 53.7 \\
17) Holoceno & 0.1 & 53.7 & 23.7 & 22.4 & 1.02 & 73.6 \\
18) Las Cortaderas 2 & 0.0 & 27.4 & 69.4 & 3.2 & 0.72 & 51.9 \\
19) Vega Linda & 0.5 & 40.5 & 45.2 & 13.8 & 1.02 & 73.9 \\
20) Las Cortaderas 3 & 0.0 & 43.5 & 42.7 & 13.7 & 1.00 & 72.0 \\
21) La Paloma & 0.0 & 3.4 & 50.2 & 46.4 & 0.82 & 59.0 \\
22) Cuchipuy & 0.0 & 12.1 & 3.4 & 84.5 & 0.51 & 37.1 \\
\hline
\end{tabular}

The quantity of different raw material present at each site and it's proportion provide crucial information for assessing the access that the inhabitants of those sites would have had 
to these resources. We can measure these two variables using the diversity index $(H)$ developed by Shannon and Weaver (1949: 51), which is designed to measure this indicator in terms of richness and evenness and will enable us to assess the overall distribution of raw materials at the sites studied. Richness represents the quantity of different types of raw materials that are present at each site, while evenness reflects the proportion of each raw material found at each site. The value that this index $H$ attains for each site is shown in Table 1, along with the percentage that this value represents in the hypothetical case in which all raw materials are present in all sites in the same proportion, or $H \alpha$, whose value is calculated in the following way:

$$
H \alpha=\log _{\mathrm{e}}(N)
$$

in which $N$ corresponds to the total quantity of categories among which a variable is distributed, in this case the quantity of types of raw materials. This value in our case is 1.386.

Thus, we observe (Figure 2, Table 1) that the sites fall into certain relevant sets or groups. In the lower part of the distribution there is a group of three sites with low diversity of raw materials; they do not reach values higher than $15 \%$ of $H \alpha$, and one only reaches $4.8 \%$ owing to its high concentration of siliceous rocks (98.8\%). The next least diverse group yields a diversity measure $13.1 \%$ higher than the previous one. The other end of the distribution, with values greater than $65 \%$ of $H \alpha$, contains a set of seven sites that present high diversity of raw materials, with values 6.4\% higher than the second most diverse grouping. Most of the sites, however, fall into the centre of the distribution. The majority of these present values between 43 and $49 \%$ of $H \alpha$, spaced relatively evenly apart, with differences of no more than $3 \%$ between each. The remaining three sites are relatively isolated, with values ranging from 26 to $37 \%$ of $H \alpha$. The two sets of sites found at the two extremes of the distribution both present clear spatial associations, one concentrated in the Cordón de Chacabuco and the other in the southern part of the Andes Mountains (Figure 1).

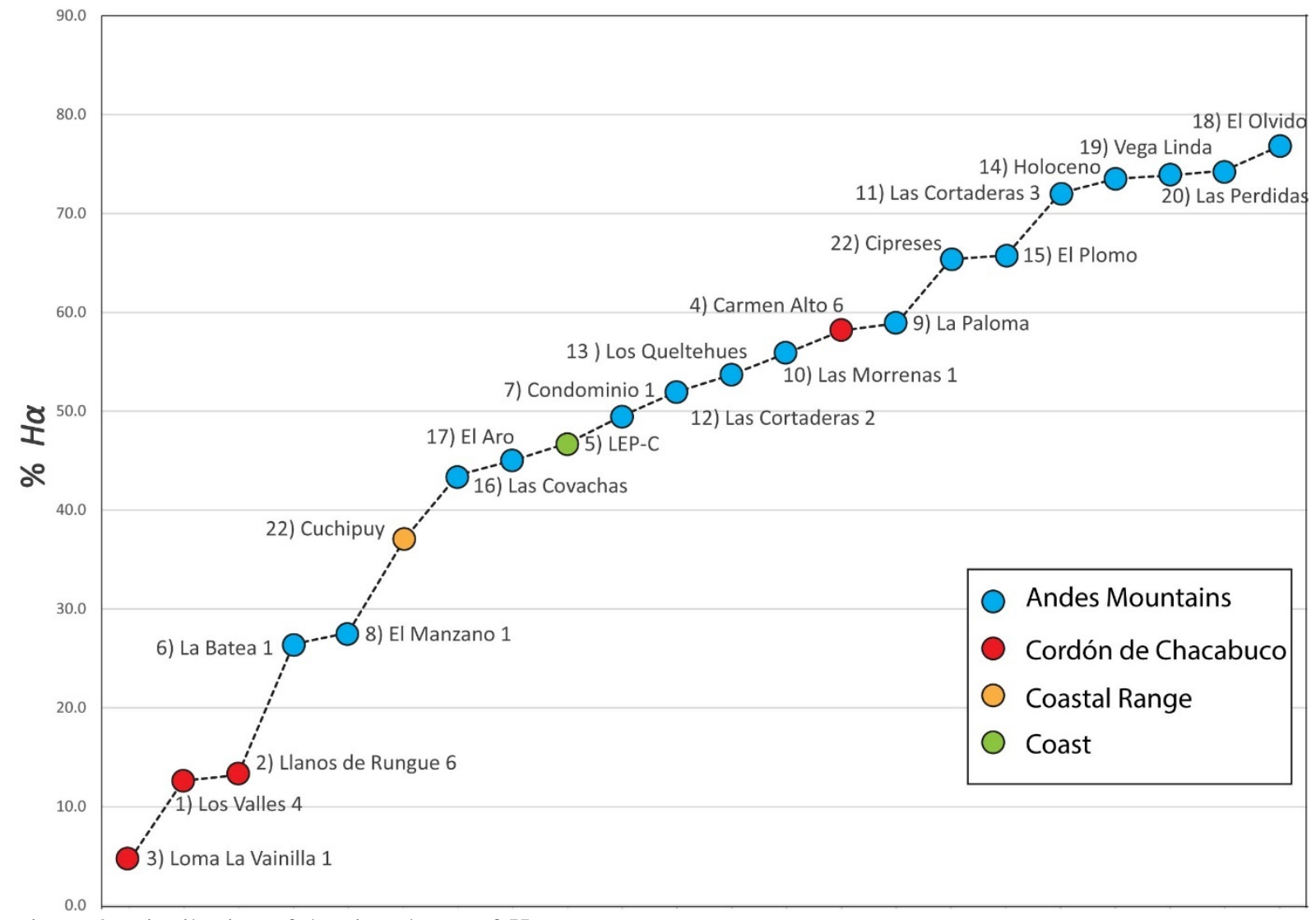

Figure 2. Distribution of the sites, by \% of $H \alpha$. 
This spatial distribution can be observed in greater detail by a principal component analysis, with Factors 1 and 2 explaining 98.49\% of the variation of the entire set (Figure 3). This analysis clearly show that the distribution of sites is determined by the relative weighting of the different raw materials and their location in space, forming spatially differentiated groups (Figure 4). Group 1 encompasses the three sites we examined on the lowest range of the $H \alpha$ percentage scale (Figure 2). They are located in the Cordón de Chacabuco and are grouped very close together by the high importance of siliceous rocks in their archaeological contexts. Nearby is the Carmen Alto 6 site, in the same locality, although the presence of $10.8 \%$ of quartz by-products shifts this site towards the quadrant where that raw material is important. Next, grouped together in the quadrant where obsidian is prevalent are 11 sites in which this raw material dominates the context, several of which fall into the higher range of $H \alpha \%$ distribution (Figure 2). All 11 sites are found in the southern part of the Andean sector, forming Group 2. This group is less compact than Group 1, with the distribution extending towards the quadrant where siliceous rocks are the protagonist, as some of this raw material begins to appear in these contexts (Table 1); but they maintain their distance from Group 1.

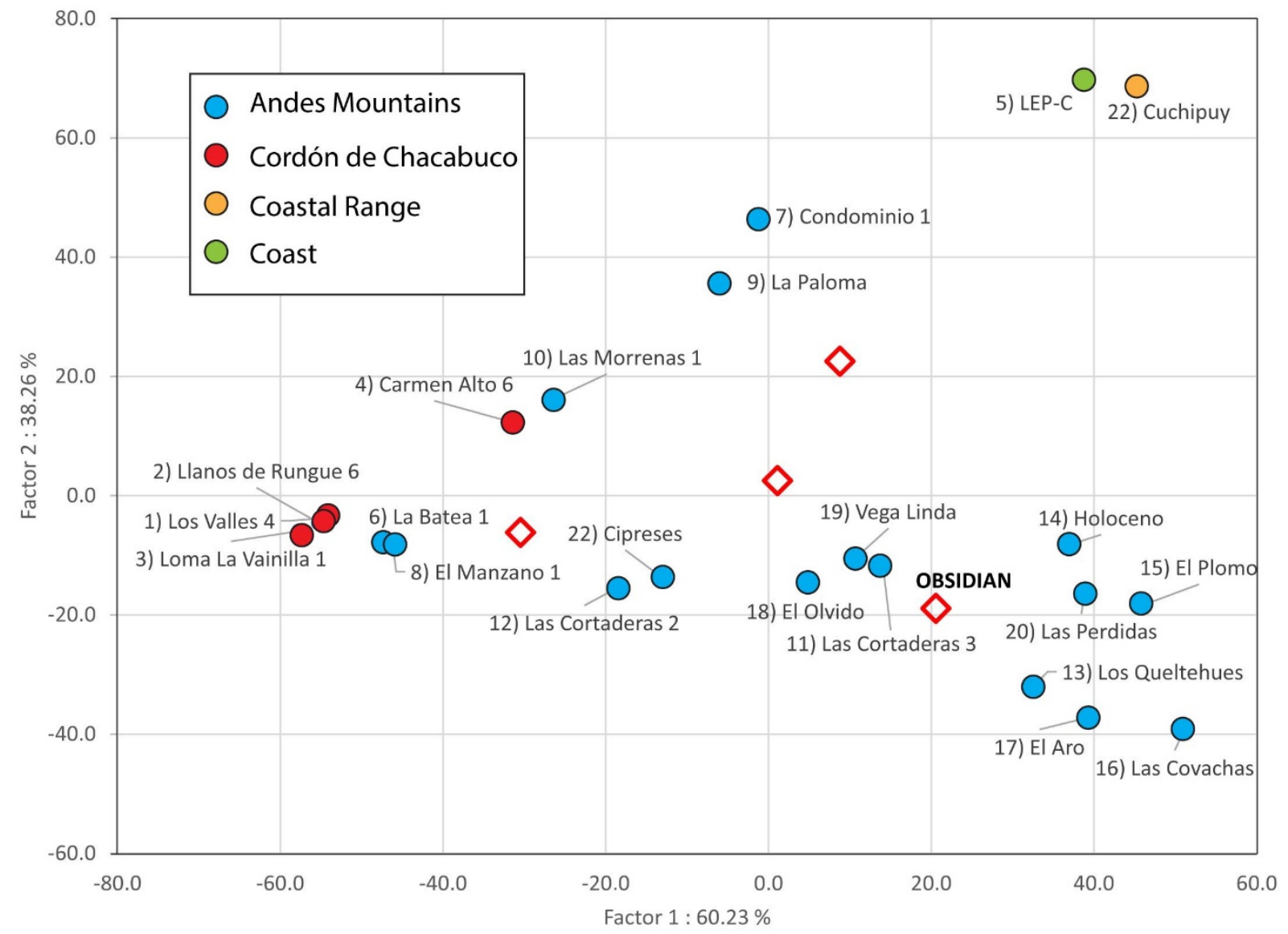

Figure 3. Distribution based on Factors $1 \& 2$ of the main component analysis of the sites studied and raw materials considered.

The rest of the Andean sites, all located in the northern zone, are spread around the quadrant with a preponderance of siliceous rocks. We have identified these as Group 3. In some sites (La Paloma and Condominio 1), the presence of waste from MCG rocks is also significant, although insufficient to justify a separate group. Evidently, this group is less homogeneous than the two previous ones.

Lastly, in the upper section of the dispersion, there are two sites whose only common feature is their high frequency of MCG rocks, although at LEP-C, quartz is the leading fine- 
grained rock, while at Cuchipuy it is obsidian (Table 1 ). The two also display very different $H \alpha$ percentage values and are in very different locations.

At the LEP-C site, located on the coast, the high frequency of quartz makes it virtually the only fine-grained raw material in its context (Table 1). A review of the collection from an excavation conducted three decades ago (Falabella \& Planella 1991) confirmed that all of the quartz present is very characteristic, having a whitish, semi-transparent colour, amorphous appearance, and structure that tends to produce more angular rather than conchoidal fractures, making it less suitable for bifacial reduction than other raw materials discussed herein. The preponderance of quartz found at LEP-C is consistent with information published about another known coastal site, Punta Curaumilla 1, where, although in initial occupations quartz is not significant, at later levels, contemporary to the sites studied herein, quartz accounts for up to $91 \%$ of waste material found in the context (Ramírez et al. 1991). This leads us to define a Group 4, on the coast.

For now, the Cuchipuy site stands alone, although more in-depth investigations in the area may identify other sites with a similar lithic composition. In fact, some information from at least one other archaeological site in the southern part of that area (Tagle \& del Río 2006) indicates it may share certain characteristics with Cuchipuy, but much more detailed studies of those findings would need to be conducted to include that site here.

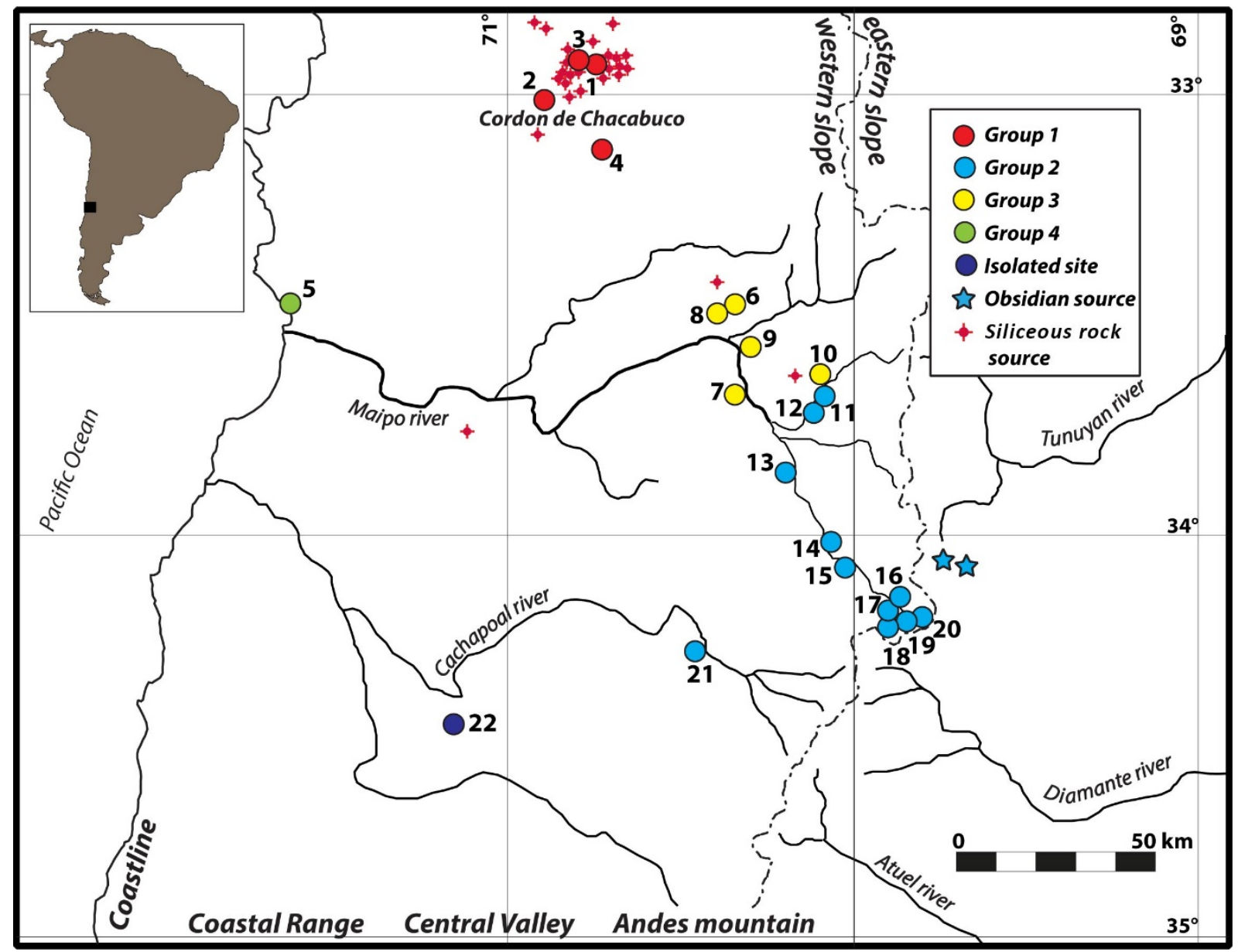

Figure 4. Spatial distribution of the sites classified according to the groups to which they belong.

Based on their location and the configuration of raw materials found within them, these groups of archaeological sites are largely consistent with the lithic landscape described above (Figure 4). The sites of Group 1, in which siliceous rocks predominate, are located near the 
abundant sources of this raw material in the Cordón de Chacabuco. The sites of Group 2, where obsidian predominates, are near the sources of that raw material in the Andean volcanic zone. Group 3, for its part, is in a zone where at least two sources of siliceous rocks have been identified, and despite it being a mountainous territory, like that of Group 2, there are no sources of obsidian nearby. Lastly, Group 4, for which we have used our own data for the LEP-C site and published data for the Punta Curaumilla 1 site (Ramírez et al. 1991), is in the coastal region, which, despite the lack of archaeologically-identified sources where this rock was extracted, is known geologically to contain it (Godoy 1994; Parada 1992).

Thus, it can be affirmed that in Central Chile, the contexts associated with the use of lithic raw materials is directly associated with the lithic landscape present. This could be interpreted as the obvious result of a strategy of economic maximization, in which the inhabitants use the materials that were most abundant in each place, to avoid having to transport cores, bifaces, or other performs. Nevertheless, some aspects of the distribution of these raw materials in Central Chile challenge this simple economic interpretation and points rather to the existence of groups with socially-differentiated access to existing lithic resources.

First of all, as some of us have argued previously (Cornejo \& Sanhueza 2011), in the Andean basin of the Maipo River, it is possible to identify two territories occupied by two different hunter-gatherer communities, corresponding approximately to Groups 2 and 3 defined herein, each with different access to sources of raw lithic materials. In that study (Cornejo \& Sanhueza 2011: 495-497) we indicated that the distance to sources of obsidian, the only raw material with clearly-defined sources which are extremely localized, while it explains $59 \%$ of the difference in obsidian frequency at the sites $\left(r^{2}=0.59\right)$, also leaves a percentage variation in the quantity of obsidian larger than what can be explained by distance alone. In this analysis, where we consider a much broader territory, and where at first glance it also seems evident that the most distant sites contain less obsidian, we see that the regression between distance and percentage of obsidian only leads to a small increase in the dependent variable (\% of obsidian) as explained by the independent variable (distance), from $59 \%$ to $63 \%\left(r^{2}=0.63\right)$.

Moreover, there is an area in Andean basin of the Maipo River, the Yeso River (Figure 5), where the difference among sites classed as Group 2, with a predominance of obsidian, and those of Group 3, with much more diverse raw materials, is in practice impossible to explain simply on the basis of distance from obsidian sources alone. This area includes three sites, Las Cortaderas 2, Las Cortaderas 3 on the southern bank of the river, and Las Morrenas 1 on the northern edge, that present dramatically different proportions of obsidian. While at Las Morrenas 1 the percentage of obsidian is just 4.5\%, in Las Cortaderas 3, just $3.3 \mathrm{~km}$ away, on the other side of the river, that percentage is $44.0 \%$, and at Las Cortaderas 2, some $5.4 \mathrm{~km}$ from Las Morrenas 1, also on the southern bank, the percentage is $27.4 \%$ (Table 1 ). In other words, the access to obsidian among contemporary hunter-gatherer groups that occupied sites just across the river from each other varied by a factor of 5-10:1. We can therefore argue that the percentage of obsidian is not related strictly to distance from the sources of these raw materials, which is practically the same; instead, it is more likely that the difference arises from socially differentiated access to those sources (Cornejo \& Sanhueza 2011).

Albeit to a different degree, we also contend that the scenario among Group 4 coastal sites also clearly expresses the presence of socially differentiated access to certain lithic resources. At the LEP-C site, for example, the presence of other fine-grained, non-quartz rocks is very low, amounting to just $1.1 \%$ for obsidian and $3.2 \%$ for siliceous rocks (Table 1), and similar figures have been reported for the Punta Curaumilla 1 site (Ramírez et al. 1991). However, quartz, which is part of the coastal lithic landscape, is much less suitable for bifacial reduction than siliceous rocks or obsidian. The very limited access to obsidian can be explained by the $213 \mathrm{~km}$ distance over which group members would have had to transport that rock from its closest source at Laguna del Diamante (Figure 2). But the same reasoning does not seem 
sufficient to explain the low quantity of siliceous rock by-products at the site, when abundant sources of that raw material can be found just over $75 \mathrm{~km}$ away in the Cordón de Chacabuco sector, and perhaps even closer, as geological information (Nasi \& Thiele 1982) attests to the presence of this kind of raw material just $55 \mathrm{~km}$ away in the coastal range itself (Figure 2).

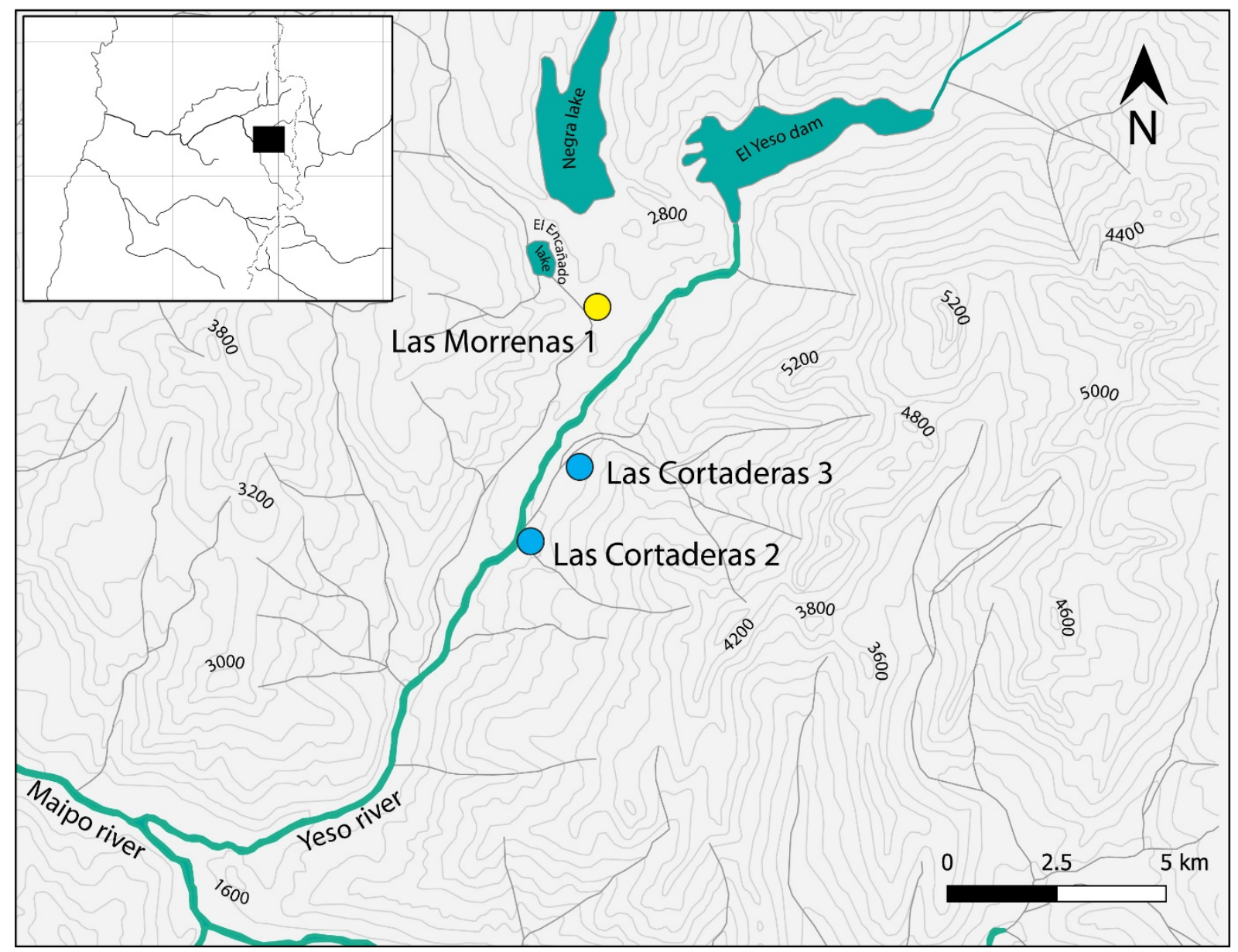

Figure 5. Yeso River locality

Additionally, it is worth considering whether the total size of the space within which the sites studied are found, and the distances between each of the sites, could be pivotal in defining these groups, making this essentially a matter of their mobility.

As there is no archaeological frame of reference that could help with this definition, or none that would not be tautological, we turned to existing ethnographic records. Obviously, this kind of analogy has serious limitations, particularly as there are no ethnographic records for groups occupying a region ecologically similar to the one in question, the temperate forests of our area, and because from a more general perspective, most ethnographic studies focus on groups that had already come into some kind of contact with industrialized societies.

The set of ethnographic data published by Binford (2001: Table 5.01) offers us a precise comparison for assessing annual mobility ranges of a large number of effectively mobile huntergatherer groups. Analysis of that information (Table 2) allows us to observe that, while there is high diversity within a minimum of $3 \mathrm{~km}$ and a maximum of $570 \mathrm{~km}$ yearly $(\underline{x}=171 \mathrm{~km} \sigma$ $=144$ ), $49.8 \%$ of the groups studied moved more than $120 \mathrm{~km}$ per year, and in fact, 36.6\% covered more than $200 \mathrm{~km}$ annually. Thus, when we consider the area encompassed by the dispersed sites studied here, where the maximum distance along the optimal route between the most distant points is just $192 \mathrm{~km}$, we can conclude it is very likely that a single group could have covered the entire territory under study here. It would thus be surprising if, when traveling 
down to the coast, hunter-gatherers would not have brought rocks suitable for reduction (siliceous rocks and obsidian) that are not present in the coastal lithic landscape, or if, when crossing the Yeso River, they would have thrown away almost all of their provision of obsidian.

Using the same data set provided by Binford (2001: Table 5.01), we observe that the size of the territory occupied by different mobile hunter-gatherer groups (Table 3) is, as one would expect from the mobility data, very diverse, with a minimum area of $80 \mathrm{~km}^{2}$ and a maximum of $660,000 \mathrm{~km}^{2}\left(\underline{x}=42.260 \mathrm{~km}^{2} \sigma=91.948\right)$. However, $65.1 \%$ of Binford's cases occupied a territory less than or equal to that covered by our sites $\left(17,133 \mathrm{~km}^{2}\right)$ and a major percentage (48.9\%) had territories that were half the size or less than the territory covered by our sites. This information, which shows that there are enough examples of hunter-gatherer groups that occupied territories much smaller than the space available in Central Chile, makes it plausible that four different hunter-gatherer groups existed within the territory studied at the same time.

Table 2. Frequency and proportion of ethnographic hunter-gatherer groups, by annual mobility range. (Data taken from Binford 2001: Table 5.01).

\begin{tabular}{lcc}
\hline Distance (in km) & Frequency & \% \\
\hline 20 & 22 & 9.4 \\
40 & 32 & 13.6 \\
60 & 17 & 7.2 \\
80 & 21 & 8.9 \\
100 & 22 & 9.4 \\
120 & 4 & 1.7 \\
140 & 10 & 4.3 \\
160 & 9 & 3.8 \\
180 & 8 & 3.4 \\
200 & 4 & 1.7 \\
$>200$ & 86 & 36.6 \\
\hline
\end{tabular}

Table 3. Frequency and proportion of ethnographic hunter-gatherer groups, by territory size range. (Data taken from Binford 2001: Table 5.01).

\begin{tabular}{lcc}
\hline Area (in $\left.\mathbf{k m}^{\mathbf{2}}\right)$ & Frequency & $\mathbf{\%}$ \\
\hline 2000 & 45 & 19.1 \\
4000 & 39 & 16.6 \\
6000 & 16 & 6.8 \\
8000 & 15 & 6.4 \\
10000 & 14 & 6.0 \\
12000 & 10 & 4.3 \\
14000 & 3 & 1.3 \\
16000 & 5 & 2.1 \\
18000 & 6 & 2.6 \\
20000 & 2 & 0.9 \\
$>20000$ & 80 & 34.0 \\
\hline
\end{tabular}

\section{Discussion and Conclusions}

According to the analyses conducted, the proportion of lithic raw materials, recorded as by-products of reduction at hunter-gatherer archaeological sites in Central Chile, allows us to define four groups, each associated with the lithic landscapes of the different regions in which they are situated, especially in regard to the fine-grained raw materials most suitable for bifacial 
reduction. These groups could not have resulted from a simple cost-benefit analysis by a single group that moved around the entire territory, accessing the raw materials from sources available in the respective lithic landscapes.

In this way, it can be stated that the access to different sources of raw lithic material was subject to some restrictions, which suggests the existence of groups with socially differential access to certain sources. For the Andean area, some of us have argued previously (Cornejo \& Sanhueza 2011) that the differential access to raw materials such as siliceous rocks and obsidian; the differential use of different types of camps; and, among later hunter-gatherers, different forms of interaction with contemporary semi-sedentary horticultural groups, all point to the presence of two well-defined, socially differentiated communities. These two huntergatherer communities correspond to what we have named Groups 2 and 3 here.

Furthermore, the sites that comprise what we have called Group 1, are all located in the Cordón de Chacabuco, and present not only a special concentration of siliceous rocks, which is abundant in the locality, but also other features that could reinforce their identification as a socially distinct group. All of the sites studied, and most of those recognized in our field surveys (Cornejo \& Saavedra 2017), are open-air sites associated with one or more boulders with multiple mortars perforated into the rock, called locally as piedras tacitas ("cup stones"). While we do not yet know precisely what their creators crushed within those mortars (Belmar \& Carrasco 2017; Planella \& McRostie 2017; Planella et al. 2018), their frequent occurrence in the Cordón de Chacabuco indicates that the place offered some kind of resource that was of special interest to its ancient inhabitants.

Beyond those features, however, we must also consider the location of sites with piedras tacitas (Cornejo \& Saavedra 2017; Planella et al. 2018), which reveals particular features not found among the other groups defined herein. First of all, each site has several mortars, which means that the activities carried out there could have been collective. Second, most sites are positioned so that the tasks carried out there would have been very visible to others in the surrounding area, which implies that those activities would have been public. These two features, collective work and public exposure, are not present at sites in any other group defined here and, we believe, when combined with the easy access to sources of siliceous rocks in the locality, points to the existence of a third group in the area of the Cordón de Chacabuco with a habitus (Bourdieu 1977) that is clearly distinct from that of other hunter-gatherer groups in the region.

Lastly, the scenario on the coast also seems to display some particularities. Despite the evidently small sample size, the few sites studied also represent a group distinct from those already defined in the interior. This is especially highlighted by the almost complete absence of siliceous rocks and obsidian by-products, indicating that the groups living in this area had very restricted access to the sources of these rocks, and could only work with the inferior-quality quartz that was available on the coast. The evidence supplied by the lithic context is reinforced by an analysis of $\delta^{15} \mathrm{O}$ isotopes of four individuals buried at the LEP-C site (Falabella \& Sanhueza 2019), which showed that they lived on the coast for most of the year.

Thus, privileged access to certain resources would be representative of social differences among the hunter-gatherer groups of Central Chile, and, as we have mentioned, is also linked to other aspects of the social lives of these groups. As we have seen, the ethnographic data on mobility range and territory size (Binford 2001: Table 5.01) demonstrate that the situation described here is compatible with those observed by ethnographers in many hunter-gatherer groups.

Still, this social configuration of the space does not mean that territories were completely hermetic; rather, it indicates that this practice occurred as part of what Ingold (1986) called a one-dimensional territorial strategy, in which control of certain resource sources does not imply control of a two-dimensional space, as defined by a perimeter. A clear example of this is the 
circulation of small amounts of obsidian from the only available sources, within the territory of Group 2 sites, to distant sites such as LEP-C and Carmen Alto 6 (Table 1), which means people moved around and transported this rock outside of the territory where it originated. The same can be said for the small percentage of siliceous rocks that came to the coast, very probably from sources in the Cordón de Chacabuco. This definition of territory is especially evident in the late period in the space occupied by Groups 2 and 3, where they closely co-existed, embedded among semi-sedentary horticultural groups, with some settlements less than a kilometre from each other (Cornejo \& Sanhueza 2003; 2011). These semi-sedentary horticulturalists would also have had access, albeit to a lesser degree, to the fine-grained raw materials used by the hunter-gatherers.

Finally, it is evident that the space occupied by the four distinct groups defined here does not truly represent the entire geographic extension of the territory in which they ranged; it simply represents the degree of knowledge we have today about hunter-gatherer occupations in Central Chile. For Group 2, as mentioned (Cornejo \& Sanhueza 2011), the information available about the eastern Andean watershed (Durán et al. 2006; Lagiglia 1997; Lagiglia et al. 1994; Neme et al. 2016) just over the Andes from the space where this group is situated, indicates that its area of mobility would have included that basin. And one could imagine that Group 1's mobility circuits extended to the semi-arid north, where a north-south mobility pattern has already been proposed in which the availability of siliceous rocks sources was a defining element (Galarce 2014: 113).

\section{Acknowledgements}

This work is the result of studies conducted under FONDECYT projects 1090200, 1970071 and 1930212.

\section{References}

Aguilera, P. 2012, Contribuciones metodológicas al estudio de fuentes y características visibles de sílices: el caso de Rungue-Montenegro (R.M.-Chile). In: Actas del XVIII Congreso Nacional de Arqueología Chilena, Sociedad Chile de Arqueología, Santiago, Chile: p. 309-316. (in Spanish) ("Methodological contributions to the study of sources and visible characteristics of silisous rocks: the case of Rungue-Montenegro (R.M.Chile)")

Belmar, C. \& Carrasco, C. 2017, Análisis multiproxy para una perspectiva integradora en el entendimiento de la explotación de los recursos vegetales presentes en las ocupaciones del área de Carmen Alto, Colina, Región Metropolitana. In: Actualización en el estudio de Piedras Tacitas: Nuevas perspectivas (Belmar, C., Contreras, L. \& Reyes, O., Eds.) Serie Monográfica Sociedad Chilena de Arqueología Vol. 6, Sociedad Chilena de Arqueología Santiago, Chile: p. 163-184. (in Spanish) ("Multiproxy analysis for an integrative perspective in the understanding of the exploitation of plant resources present in the occupations of the Carmen Alto area, Colina, Metropolitan Region")

Binford, L. R. 1979. Organization and formation processes: looking at curated technologies. Journal of Anthropological Research, 35(3): 255-273.

URL: https://www.jstor.org/stable/3629902

Binford, L.R. 2001, Constructing frames of reference : An analytical method for archaeological theory building using hunter-gatherer and environmental data sets. University of California Press, Berkeley, 583 p. 
Bourdieu, P. 1977, Outline of a theory of practice. Cambridge Studies in Social Anthropology Vol. 16. Cambridge University Press, Cambridge ; New York, 248 p.

Castelleti, J. \& García, M. 2007, Detección y caracterización de fuentes prehispanas de aprovisionamiento lítico a través de indicadores geológico-arqueológicos en el Cordón de Chacabuco (Chile Central). Revista Clava, 6: 47-58. (in Spanish) ("Detection and characterization of pre-Hispanic sources of lithic supply through geologicalarchaeological indicators in the Cordon de Chacabuco (Central Chile)")

Cornejo, L. 2010, Arqueología de cazadores recolectores en Chile Central: una síntesis de lo avanzado, las limitaciones y las aspiraciones. Revista Werkén, 13(2): 69-83. (in Spanish) ("Hunter gatherers’s Archaeology in Central Chile: A synthesis of the advanced, limitations and aspirations")

Cornejo, L., Falabella, F. \& Sanhueza, L. 2003, Patrón de asentamiento y organización social de los grupos Aconcagua de la cuenca del Maipo. Revista Chilena de Antropología, 17: 77-104. (in Spanish) ("Settlement pattern and social organization of Aconcagua groups in the Maipo basin"). doi:10.5354/0719-1472.2011.17357

Cornejo, L., Falabella, F., Sanhueza, L. \& Correa, I. 2012, Patrón de asentamiento durante el periodo Alfarero en la cuenca de Santiago, Chile Central. Una mirada a la escala local. Intersecciones en antropología, 13(2): 449-460. (in Spanish) ("Alfarero periods settlement pattern in the Santiago basin, Central Chile. A look at the local scale")

Cornejo, L. \& Galarce, P. 2010, C index: Dimensioning the expedient/curative continuum in lithic technology. Chungara, Revista de Antropología Chilena, 42(2): 393-404. doi:10.4067/S0717-73562010000200004

Cornejo, L. \& Saavedra, M. 2017, Historia ocupacional de las piedras tacitas (morteros múltiples en rocas) del trasecto Rungue-Montenegro (Cordón de Chacabuco, Chile Central). In: Actualización en el estudio de Piedras Tacitas: Nuevas perspectivas (Belmar, C., Contreras, L. \& Reyes, O., Eds.) Serie Monográfica Sociedad Chilena de Arqueología Vol. 6, Sociedad Chilena de Arqueología, Santiago, Chile: p. 92-116. (in Spanish) ("Occupational history of the multiple mortar rocks of the RungueMontenegro (Cordón de Chacabuco, Central Chile)")

Cornejo, L., Saavedra, M. \& Galarce, P. 2005, Los estratos antiguos de El Manzano 1 en el contexto del Arcaico Temprano en Chile Central. In: Actas del XVI Congreso Nacional de Arqueología Chilena, Sociedad Chilena de Arqueología, Tome, Chile: p. 415-424. (in Spanish) ("The ancient layers of El Manzano 1 in the context of the Early Archaic in Central Chile")

Cornejo, L., Saavedra, M. \& Vera, H. 1998, Periodificación del Arcaico en Chile central: Una propuesta. Boletín de la Sociedad Chilena de Arqueología, 25: 36-39. (in Spanish)

("Archaic periodification in Central Chile: A proposal")

Cornejo, L., Saavedra, M. \& Vera, H. 2000, Asentamientos arcaicos tardíos en El Manzano (Río Maipo). In: Actas del XIV Congreso Nacional de Arqueología Chilena: Contribución Arqueológica, Sociedad Chilena de Arqueología: p. 621-636. (in Spanish) ("Late Archaic Settlements in El Manzano (Río Maipo)")

Cornejo, L. \& Sanhueza, L. 2003, Coexistencia de cazadores recolectores y horticultores tempranos en la cordillera Andina de Chile Central. Latin American Antiquity, 14(4): 389-407. (in Spanish) ("Early hunter gatherers and horticulturists's coexistence in the Andean mountain range of Central Chile") doi:10.2307/3557575 
Cornejo, L. \& Sanhueza, L. 2011, North and South: Hunter-gatherer communities in the Andes mountains in Central Chile. Latin American Antiquity, 22(4): 487-504. doi:10.7183/1045-6635.22.4.487

Cornejo, L. \& Simonetti, J. 1993, Asentamiento humano en los Andes de Chile central: un enfoque alternativo. In: Actas del XII Congreso Nacional de Arqueología Chilena Vol. 2, Sociedad Chilena de Arqueología, Temuco, Chile: p. 373-380. (in Spanish) ("Human Settlement in the Andes of Central Chile: An Alternative Approach")

Cornejo, L. \& Simonetti, J. 1997, De rocas y caminos: espacio y cultura en los Andes de Chile Central. Revista Chilena de Antropología, 14: 127-144. (in Spanish) ("On rocks and roads: space and culture in the Andes of Central Chile"). doi:10.5354/07191472.2011.17507

Cortegoso, V., Glascock, M., De Francesco, A.M., Durán, V., Neme, G., Gil, A., Giesso, M., Sanhueza, L., Cornejo, L. \& Barberena, R. 2014, Chemical characterization of obsidian in central western Argentina and Central Chile: archaeological problems and perspectives. In: Physical, chemical and biological markers in argentine archaeology: theory, methods and applications (Morales, D.M.K. \& M, Eds.) BAR International Series, Archaeopress, Oxford: p. 17-26.

Cortegoso, V., Yebra, L., Durán, V., Barberena, R., Lucero, G., Cornejo, L., Giesso, M., MacDonald, B.L. \& Glascock, M.D. 2020, Obsidian sources from the southern Andean highlands (Laguna del Diamante, Argentina and Chile): geochemical insights on geological complexity and human biogeography. Archaeological and Anthropological Sciences, 12(1): 1-11. doi:10.1007/s12520-019-01009-w

Durán, V., Giesso, M., Glascock, M., Neme, G., Gil, A. \& Sanhueza, L. 2004, Estudio de fuentes de aprovisionamiento y redes de distribución de obsidiana durante el Holoceno Tardío en el sur de Mendoza (Argentina). Estudios atacameños, 28: 25-43. (in Spanish) ("Studies of supply networks and distribution networks of obsidian during the Late Holocene in southern Mendoza (Argentina)"). doi:10.4067/S0718-10432004002800004

Durán, V., Neme, G., Cortegoso, V. \& Gil, A. 2006, Arqueología del área natural protegida Laguna del Diamante (Mendoza, Argentina). Anales de Arqueología y Etnología, 61: 81-134. (in Spanish) ("Archaeology of the Laguna del Diamante protected natural area (Mendoza, Argentina)")

Dyson-Hudson, R. \& Smith, E.A. 1978, Human territoriality: An ecological reassessment. American Anthropologist, 80(1): 21-41.

URL: https://anthrosource.onlinelibrary.wiley.com/doi/pdf/10.1525/aa.1978.80.1.02a00 020

Falabella, F. \& Planella, M.T. 1991, Comparación de ocupaciones precerámicas y agroalfareras en el litoral de Chile central. In: Actas XI Congreso Nacional de Arqueología Chilena Vol. 3, Museo Nacional de Historia Natural y Sociedad Chilena de Arqueología Santiago, Temuco, Chile: p. 95-112. (in Spanish) ("Comparison of preceramic and agro-pottery occupations on the coast of Central Chile")

Falabella, F. \& Sanhueza, L. 2019, Living on the coast without depending on coastal resources. Isotopic evidence in Central Chile. Journal of Archaeological Science: Reports, 26: 101890. doi:10.1016/j.jasrep.2019.101890

Freeman, J. \& Anderies, J.M. 2015, The socioecology of hunter-gatherer territory size. Journal of Anthropological Archaeology, 39: 110-123. doi:10.1016/j.jaa.2015.03.002 
Gajardo Tobar, R. 1958, Investigaciones acerca de las" Piedras con tacitas" en la zona central de Chile. Anales de Arqueología y Etnología, (14-15): 163-204. (in Spanish) ("Multiple mortar rocks's research in the central area of Chile")

Galarce, P. 2014, Bifacialidad, circulación de materias primas y movilidad de comunidades cazadoras recolectoras holocénicas en el Semiárido meridional, Master's disseretation at the Departamento de Antropología, Universidad de Tarapacá - Universidad Católica del Norte, Arica, 457 p. (in Spanish) ("Bifaciality, circulation of raw materials and mobility of hologenic collecting hunter communities in the southern Semi-arid")

Galarce, P. \& Peralta, P. 2003, Organización tecnológica lítica y movilidad de grupos cazadores recolectores en asentamientos cordilleranos del Arcaico tardío en Chile Central. In: XVI Congreso Nacional de Arqueología Chilena, Museo de Historia Natural de Concepción, Sociedad Chilena de Arqueología, Concepción, Chile: p. 435-444. (in Spanish) ("Lithic technological organization and mobility of hunter gatherers groups in the Cordillera's Late Archaic's settlements in Central Chile")

Godoy, E. 1994, Reflexiones acerca de transiciones metamorficas en el basamento de Chile central-sur. Revista Geológica de Chile, 23:79-86. (in Spanish) ("Reflections on metamorphic transitions in the basement of central-south Chile")

URL: https://bdigital.uncuyo.edu.ar/objetos_digitales/13915/rev-anales-1958-59-vol1415nuevo-parte6.pdf

Hermosilla, N. 1994, Alero Las Chilcas 1: 3.000 años de secuencia ocupacional. In: II Taller de Arqueología de Chile Central., www.arqueologia.cl, Santiago, Chile. (in Spanish) ("Las Chilcas 1 rockshelter: 3,000 years of occupational sequence")

URL: http://www.arqueologia.cl/actas2/hermosilla.pdf

Hermosilla, N. \& Ramírez, J.M. 1985, Las Cenizas: evidencias de ritualismo en torno a piedras tacitas. In: Actas del IX Congreso Nacional de Arqueología Chilena. La Serena, Chile, Sociedad Chilena de Arqueología, La Serena: p. 306-320. (in Spanish) ("Las Cenizas 1: evidence of ritualism around multiple mortar rocks")

Hermosilla, N., Saavedra, B. \& Simonetti, J. 1995, Ocupación humana en el sector de Las Chilcas: aleros Las Chilcas 2 y Piedra del Indio. In: Actas del XIII Congreso Nacional de Arqueología Chilena, Antofagasta, Universidad de Antofagasta. Sociedad Chilena de Arqueología, Copiapó, Chile: p. 275-280. (in Spanish) ("Human occupation in the Las Chilcas sector: Las Chilcas 2 and Piedra del Indio rockshelters")

Ibacache, S. \& G. Cantarutti, Nuevas investigaciones en el Cerro Peladeros: Una huaca del periodo incaico en la cordillera de Chile Central. Revista Werkén, 10: 63-79. (in Spanish) ("New investigations in Cerro Peladeros: A huaca from the Inca period in the Cordillera of Central Chile ")

Ingold, T. 1986, Territoriality and tenure: the appropriation of space in hunting and gathering societies. In: The appropriation of nature. Essays of Human ecology and social relations (Ingold, T., Ed.), Manchester University Press, Manchester: p. 130-164.

Jerardino, A., Castilla, J.C., Ramírez, J.M. \& Hermosilla, N. 1992, Early coastal subsistence patterns in Central Chile: a systematic study of the marine-invertebrate fauna from the site of Curaumilla-1. Latin American Antiquity, 3(1): 43-62. doi:10.2307/971929

Kelly, R.L. 2013, The lifeways of hunter-gatherers: the foraging spectrum. Cambridge University Press, Cambridge, 362 p. 
King, G.E. 1976, Society and territory in human evolution. Journal of Human Evolution, 5(4): 323-331. doi:10.1016/0047-2484(76)90035-X

Lagiglia, H. 1997, Arqueología de cazadores-recolectores cordilleranos de altura. ICN. Ediciones Ciencia y Arte., Museo de Historia Natural de San Rafael, 387 p. (in Spanish) ("Archaeology of high-altitude hunters-gatherers")

Lagiglia, H.A., Neme, G. \& Gil, A. 1994, Informe en los trabajos de campo en el sitio El Indígeno (3er campaña arqueológica, Febrero de 1994). In: Actas y Memorias del XI Congreso Nacional de Arqueología Argentina Vol. 2, Museo de Historia Natural de San Rafael, San Rafael, Argentina: p. 116-118. (in Spanish) ("Field work report on the site of the Indigenous (3rd archaeological campaign, February 1994)")

Nasi, C. \& Thiele, R. 1982, Estratigrafía del Jurásico y Cretácico de la Cordillera de la Costa, al sur del Río Maipo, entre Melipilla y Laguna de Aculeo (Chile Central). Revista Geológica de Chile, 16: 81-99. (in Spanish) ("Jurassic and Cretaceous stratigraphy of the coastal mountain range, south of the Maipo River, between Melipilla and Laguna de Aculeo (Central Chile)")

Neme, G., Sugrañes, N., Salgán, L., Gil, A., Otaola, C., Giardina, M., Morgan, C. \& Llano, C. 2016, Risco de los Indios: Ocupaciones humanas de altura en la Cuenca del río Diamante. Relaciones de la Sociedad Argentina de Antropología, 41(1): 101-130. (in Spanish) ("Risco de los Indios: High-altitude human occupations in the Diamante River Basin")

Parada, M. 1992, Contribucion a la geoquimica del Complejo Plutonico Papudo Quintero, Chile Central: implicancias petrogeneticas. Andean Geology, 19(2): 199-210. (in Spanish) ("Contribution to the geochemistry of the Papudo Quintero Plutonic Complex, Central Chile: petrogenetic implications") doi:10.5027/andgeoV19n2-a04

Planella, M.T., Cornejo, L. \& Tagle, B. 2005, Alero Las Morrenas 1: evidencias de cultígenos entre cazadores recolectores de finales del período Arcaico en Chile Central. Chungara Revista de Antropología Chilena, 37(1): 59-74. (in Spanish) ("Las Morrenas 1 rockshelter: Evidence of cultigens among hunters gatherers from the end of the archaic period in Central Chile"). doi:10.4067/S0717-73562005000100005

Planella, M.t. \& McRostie, V. 2017, Piedras tacitas en el área Tiltil-Rungue-Montenegro en Chile Central. Sobre posibles usos y significados. In: Actualización en el estudio de Piedras Tacitas: Nuevas perspectivas (Belmar, C., Contreras, L. \& Reyes, O., Eds.) Serie Monográfica Sociedad Chilena de Arqueología Vol. 6, Sociedad Chilena de Arqueología, Santiago, Chile: p. 151-162. (in Spanish) ("Multiple mortar rocks in the Tiltil-Rungue-Montenegro area in Central Chile. About possible uses and meanings")

Planella, M.T., Santander, G. \& McRostie, V. 2018, Estudio morfo-tecnológico y análisis de microfósiles en piedras tacitas de Chile central. In: De las muchas historias entre las plantas y la gente. Alcances y perspectivas de los estudios arqueobotánicos en América Latina. (Belmar, C.L. \& Mora S., Eds.) BAR International Series, Instituto Colombiano de Antropología e Historia ICANH, Bogotá, Colombia: p. 261-295. (in Spanish) ("Morpho-technological study and analysis of microfossils in multiple mortar rocks from Central Chile")

Ramírez, J.M., Hermosilla, N., Jerardino, A. \& Castilla, J.C. 1991, Análisis bio-arqueológico preliminar de un sitio de cazadores recolectores costeros: Punta Curaumilla-1, Valparaíso. In: Actas del XI Congreso Nacional de Arqueología Chilena Vol. 3, Museo Nacional de Historia Natural y Sociedad Chilena de Arqueología, Santiago, Chile: p. 
81-93. (in Spanish) ("Preliminary bio-archaeological analysis of a site of coastal hunters gatheres: Punta Curaumilla-1, Valparaíso")

Reyes, O. \& Contreras, L. 2017, Ocupaciones humanas del holoceno tardío en quebrada Carmen Alto (Comuna de Colina, Región Metropolitana). De la recurrencia del asentamiento a un área marginal. In: Actualización en el estudio de Piedras Tacitas: Nuevas perspectivas (Belmar, C.. Contreras, L. \& Reyes, O., Eds.) Serie Monográfica Sociedad Chilena de Arqueología Vol. 6, Sociedad Chilena de Arqueología, Santiago, Chile: p. 15-38. (in Spanish) ("Late Holocene human occupations in Carmen Alto brook (Colina county, Metropolitan Region")

Sanhueza, L., Cornejo, L. \& Falabella, F. 2007, Patrones de asentamiento en el período alfarero temprano de Chile central. Chungara Revista de Antropología Chilena, 39(1): 103-115. (in Spanish) ("Settlement patterns in the Early Potter period of Central Chile"). doi:10.4067/S0717-73562005000100005

Sanhueza, L., Cornejo, L., Durán, V., Cortegoso, V., Yebra, L., Glascock, M.D., MacDonald, B.L. \& Giesso, M. (in press), Sources, circulation, and use of obsidian in Central Chile, Quaternary International. (2020) doi:10.1016/j.quaint.2020.11.011

Shannon, C.E. \& Weaver, W. 1949, A mathematical model of communication. Vol. 11. University of Illinois Press . Urbana, IL., 125 p.

Stehberg, R. \& Pinto, A. 1980, Ocupaciones alfareras tempranas en quebrada El Salitral del Cordón de Chacabuco. Revista Chilena de Antropología, 3: 57-73. (in Spanish) ("Early pottery occupations in El Salitral, Chacabuco sierra"). doi:10.5354/07191472.2011.17718

Tagle, M. \& del Río, C. (2006). Túmulos funerarios en cuencas palustres del valle de Tinguiririca. Unpublished manuscript, Santiago, Chile.

Villa-Martínez, R., Villagrán, C. \& Jenny, B. 2003, The last 7500 cal yr BP of westerly rainfall in Central Chile inferred from a high-resolution pollen record from Laguna Aculeo (34 S). Quaternary Research, 60(3): 284-293. doi:10.1016/j.yqres.2003.07.007

Villa-Martínez, R., Villagrán, C. \& Jenny, B. 2004, Pollen evidence for late-Holocene climatic variability at Laguna de Aculeo, Central Chile (lat. 34 S). The Holocene, 14(3): 361-367. doi:10.1191/0959683604hl712rp 